\title{
First Report of Black Spot Disease Caused by Alternaria alternata on Sweet Persimmon Fruits
}

\author{
Jung Han Lee', Jinwoo Kim² and Youn-Sig Kwak'* \\ ${ }^{1}$ Daejung Golf Engineering Co. Ltd., Yongin 449-881, Korea \\ ${ }^{2}$ Institute of Agriculture and Life Sciences, Gyeongsang National University, Jinju 660-701, Korea
}

\begin{abstract}
Black spot of sweet persimmon, caused by Alternaria alternata, occurred in an orchard in Gyeongnam province, Korea in 2012. The symptom was appearance of 0.5 to $4 \mathrm{~cm}$ black spots on the surface of fruit. The pathogen was isolated from flesh of disease lesions. The causal agent was identified as A. alternata by morphological characteristics and sequencers of the internal transcribed spacer (ITS) 1 and ITS4 regions of rRNA. Artificial inoculation of the pathogen resulted in development of disease symptoms and the re-isolated pathogen showed characteristics of A. alternata.
\end{abstract}

Keywords Alternaria alternata, Black spot, Sweet persimmon

Sweet persimmon (Diospyros kaki L.), belonging to the genus Diospyros, is native to China. China, Japan, and Korea are major producing countries of persimmon. Anthracnose (Colletotrichum gloeosporioides), circular leaf spot (Mycosphaerella nawae), and angular leaf spot (Cercospora $k a k i)$ are generally known as the main diseases of sweet persimmon. Penicillium expensum, Penicillium spp. [1].

Botrytis sp., Cladosporium sp., Pestalotia sp. and Phompsis sp. [2] are known agents of postharvest decay in sweet persimmon. In addition, Alternaria alternata was reported as a postharvest pathogen in sweet persimmon [3]. However, occurrence of pre-harvest disease by A. alternata has not been reported. In this study, we were able to identify and verify the pathogenicity of the causal agent of black spot disease occurrence as a pre-harvest disease in sweet persimmon fruit.

DNA extraction and internal transcribed spacer (ITS) sequencing analysis. The pathogen was isolated from disease lesions of sweet persimmon fruit using a surface

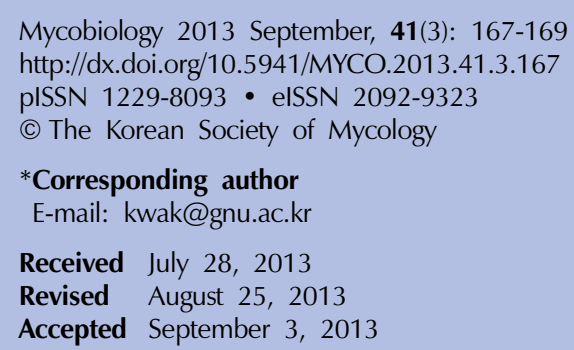

(a) This is an Open Access article distributed under the terms of the Creative Commons Attribution Non-Commercial License (http:// creativecommons.org/licenses/by-nc/3.0/) which permits unrestricted non-commercial use, distribution, and reproduction in any medium, provided the original work is properly cited. sterilization method. The pathogen was maintained at $4^{\circ} \mathrm{C}$ on potato dextrose agar (PDA). Mycelium for DNA extraction was grown in $5 \mathrm{~mL}$ of potato dextrose broth in a rotary shaker at $160 \mathrm{rpm}$ for $48 \mathrm{hr}$ at $28^{\circ} \mathrm{C}$. Total genomic DNA of the pathogen was extracted using the CTAB extraction method [4].

The ITS region was amplified using the primers ITS1 and ITS4 [5]. The amplification was performed in a $20 \mu \mathrm{L}$ reaction mixture containing $10 \mathrm{pmol}$ of each primer, two units of Taq DNA polymerase (Takara, Tokyo, Japan), $1 \mu \mathrm{L}$ of each dNTP, $2 \mu \mathrm{L}$ of $10 \times$ PCR reaction buffer, and $50 \mathrm{ng}$ of template DNA. PCR conditions were as follows: predenaturation at $94^{\circ} \mathrm{C} 5 \mathrm{~min} ; 30$ cycles of denaturing at $94^{\circ} \mathrm{C}$ for $30 \mathrm{sec}$; annealing at $55^{\circ} \mathrm{C}$ for $45 \mathrm{sec}$ and extension at $72^{\circ} \mathrm{C}$ for $40 \mathrm{sec}$; and final extension at $72^{\circ} \mathrm{C}$ for $10 \mathrm{~min}$. Sequences from the amplified ITS PCR product were deposited in GenBank (accession No. KC752593.1). Phylogenetic analysis of Alternaria alternata was performed using the MEGA5 program with the neighbor-joining method [6]. For pathogenicity testing, A. alternata was incubated for one week on PDA at $28^{\circ} \mathrm{C}$. A spore suspension adjusted to $1 \times 10^{6}$ spores $/ \mathrm{mL}$, then $10 \mu \mathrm{L}$, was inoculated on the surface of sweet persimmon fruit using a needle. Control fruits were treated with sterilized water and the inoculated sweet persimmon fruits were kept in $90 \%$ relative humidity at $28^{\circ} \mathrm{C}$ for two wk.

Disease symptom and pathogenicity test. We observed symptoms of black spot on sweet persimmon fruit from the orchard located in Jinju city, Gyeongnam province, Korea in 2012. The symptoms were similar to those of sweet persimmon anthracnose disease and the spot sizes ranged from $0.5 \sim 4 \mathrm{~cm}$. The potential causal agent of disease was isolated and purified. When the isolated fungi were 


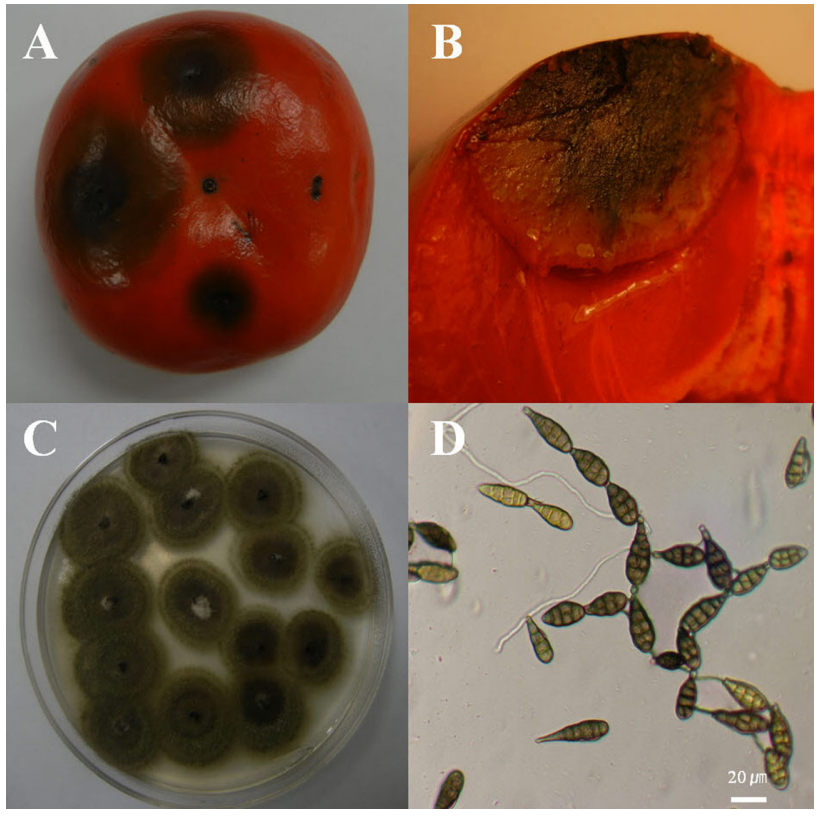

Fig. 1. Symptoms and morphological characteristics of persimmon (Diospyros kaki L.) by Alternaria alternata. A, Black spots of persimmon; B, Vertical section plan of the lesion; $\mathrm{C}$, Colony on potato dextrose agar; $\mathrm{D}$, Conidia.

inoculated artificially, the symptoms were observed on the surface of fruit at 14 days after inoculation. Small, black spots were observed on the inoculated fruit at four days after treatment. After two wk, these spots developed into large lesions (Fig. 1A). Vertical sections showed black and hard sponge symptoms (Fig. 1B), providing convincing evidence of infection through wound in the postharvest as well as the pre-harvest. The disease symptoms were similar to those of disease lesions observed on pre-harvested persimmon fruit in orchards. The fungal pathogen was re-isolated from disease lesions of inoculated fruit and the re-isolated pathogen exhibited the same morphological characteristics compared with the original isolates.

Mycological characteristics and phylogenetic analysis. The optimum temperature for mycelial growth was $25^{\circ} \mathrm{C}$ on PDA (data not shown). Mycelial colonies were typical for Alternaria (Fig. 1C). Conidiophores were simple, straight, bent, or sometimes branched. Conidia were brown, obpyriform to ellipsoid $(22 \sim 39 \times 8 \sim 15 \mu \mathrm{m})$, with both transverse and longitudinal septa (Fig. 1D). The pathogen of sweet persimmon black spot was identified as Alternaria alternata based on morphological characteristics (Table 1) [7].

The ITS sequence was compared to the GenBank database using the NCBI BLAST. The sequences determined from the rRNA-ITS were $100 \%$ similar to those of several $A$. alternata species of accession Nos. JF835809.1, JN005702.1, FJ717733.1, FJ717733.1, and JN673372.1; as a result, the causal fungus was identified as A. alternata (Fig. 2).

\section{ACKNOWLEDGEMENTS}

This research was conducted with the support of the "Cooperative Research Program for Agriculture Science \&

Table 1. Comparison of morphological characteristics of the pathogen isolated from sweet persimmon with Alternaria alternate, described previously

\begin{tabular}{llll}
\hline \hline Characteristics & & Present isolate & ${\text { Alternaria } \text { alternata }^{\text {a }}}^{\text {Colony }}$ \\
Conidia & Color & Grayish white, olive-green to sooty black & Olivaceous black to sooty black \\
& Shape & Brown, obpyriform to ellipsoid & Ellipsoid to ovoid, obclavate to obpyriform \\
& Size $(\mu \mathrm{m})$ & $22 \sim 39 \times 8 \sim 15$ & $15 \sim 35 \times 8 \sim 14$ \\
\multirow{4}{*}{ Conidiophores } & Septa & $3 \sim 5$ transverse, $1 \sim 2$ longitudinal & $3 \sim 5$ transverse, 1 (rarely 2$)$ longitudinal \\
& Shape & Simple, straight, bent or sometimes branched & Solitary or in small fascicles \\
& Size $(\mu \mathrm{m})$ & $34 \sim 100 \times 4$ & $35 \sim 110 \times 3.4$ \\
\hline
\end{tabular}

${ }^{\mathrm{a}}$ Described by Ellis [7].

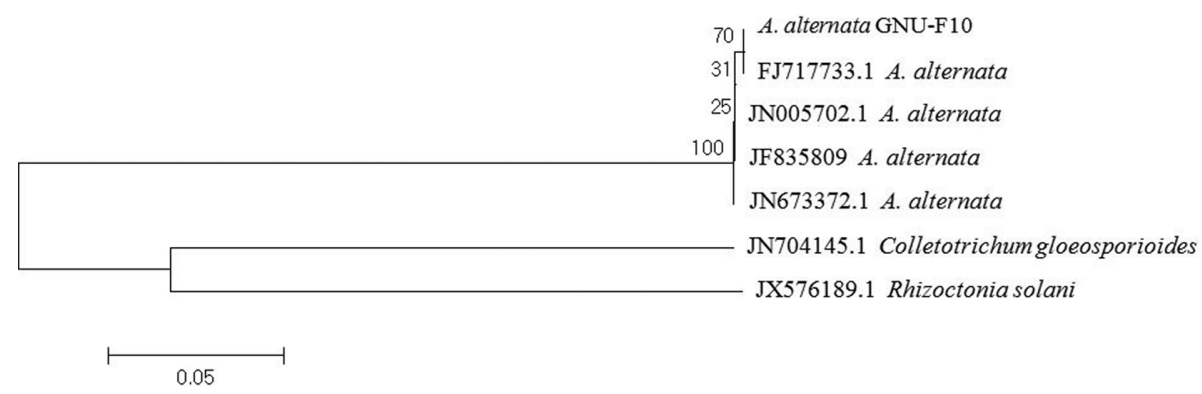

Fig. 2. Phylogenetic relationships of Alternaria alternata based on internal transcribed spacer rDNA sequences. Numerical values on branches are the bootstrap values as percentage of bootstrap replication from 1,000 replicate analyses. A phylogenetic tree was constructed using the MAGA 5 program and phylogenetic distances were calculated using the neighbor-joining method. Bar $=0.05$ genetic distance between samples. 
Technology Development (PJ009660)" from the Rural Development Administration of Korea.

\section{REFERENCES}

1. Kurt S, Soylu EM, Soylu S. First report of black spot disease caused by Alternaria alternata in persimmon fruits in Turkey. Plant Dis 2010;94:1069.

2. Kwon JH, Park CS. Sooty mold of persimmon (Diospyros kaki) caused by Cladosporum cladosporioides. Plant Pathol J 2003;19:266-8.

3. Palou L, Taberner V, Guardado A, Montesinos-Herrero C. First report of Alternaria alternata causing postharvest black spot of persimmon in Spain. Aust Plant Dis Notes 2012;7:41-
2.

4. Graham J, Marshall B, Squire GR. Genetic differentiation over a spatial environmental gradient in wild Rubus ideaus populations. New Phytol 2003;157:667-75.

5. White TJ, Bruns T, Lee S, Taylor JW. Amplification and direct sequencing of fungal ribosomal RNA genes for phylogenetics. In: Innis MA, Gelfand DH, Sninsky JJ, White TJ, editors. PCR protocols: a guide to methods and applications. New York: Academic Press; 1990. p. 315-22.

6. Tamura K, Dudley J, Nei M, Kumar S. MEGA4: molecular evolutionary genetics analysis (MEGA) software version 4.0. Mol Biol Evol 2007;24:1596-9.

7. Ellis MB. Dematiaceous Hyphomycetes. Kew, Surrey: Commonwealth Mycological Institute; 1977. 